\title{
L'ULTRASTRUCTURE DE LA PROTONÉPHRIDIE CHEZ LES MONOGĖNES. SES IMPLICATIONS POUR LA PHYLOGÉNIE DU GROUPE.
}

\author{
K. ROHDE \\ Department of Zoology, University of New England \\ Armidale, NSW, 2351, Australia.
}

\section{RÉSUMÉ}

Les petits capillaires protonéphridiens et les bulbes en flamme présentent chez les Aspidogastres, les Trématodes, les Monogènes monopisthocotylea et polyopisthocotylea une jonction septée, absente chez Udonella, les Amphilinidae, les Gyrocotylidea et les Cestodes. Les capillaires de la plupart des espèces du premier groupe possèdent des lamelles, alors que ceux du deuxième groupe (sauf Udonella) présentent de courtes microvillosités.

Les leptotriches externes sont bien développées dans le premier groupe, mais absentes ou mal développées dans le deuxième. Chez les Monogènes monopisthocotylea du genre Anoplodiscus, la jonction septée des capillaires est rudimentaire, ce qui est probablement la conséquence d'une réduction secondaire.

Les données ultrastructurales et les conclusions d'études sur l'ADN ne justifient pas l'hypothèse selon laquelle les Monogènes et les Cestodes constitueraient un taxon d'origine différente des autres groupes de Plathelminthes parasites. Ces mêmes critères (ultrastructure protonephridiale et séquence de l'ADN) assimileraient les Gyrocotylidea à des Cestodes.

\section{ULTRASTRUCTURE OF PROTONEPHRIDIA IN THE MONOGENEA. IMPLICATIONS FOR THE PHYLOGENY OF THE GROUP}

\section{SUMMARY}

The small protonephridial capillaries and flame bulbs of Trematoda Aspidogastrea, Digenea, Monogenea Polyopisthocotylea and Monopisthocotylea have a longitudinal septate junction which is absent in Udonella, Amphilinidea, Gyrocotylidea and Eucestoda. Capillaries of most species of the first group possess lamellae whereas those of the second group (except Udonella) possess short microvilli. External leptotriches are well developed in the first, but absent or weakly developed in the second group. In the monopisthocotylean monogenean Anoplodiscus, the septate junction of the capillaries is rudimentary, probably due to secondary reduction. The ultrastructural findings and DNA studies do not support the view that Monogenea and Cestoda form a taxon with an origin different from that of the other groups of parasitic Platyhelminthes. Gyrocotyle is a cestode, as indicated by the ultrastructure of the protonephridia and DNA sequencing.

\section{Introduction}

The protonephridia of Platyhelminthes are complex and slowly evolving structures and therefore useful for elucidating phylogenetic relationships between larger platyhelminth taxa. EHLERS (1985) and ROHDE $(1988,1990,1991)$, in particular, have used data on the flame bulbs for establishing a phylogenetic system of the phylum. In this paper, I evaluate opposing views on the phylogenetic relationship of the Monogenea on the basis of electron- 
microscopic findings on the protonephridia, supplemented by findings from DNA studies. LLEWELLYN (1986) has suggested that the Monogenea and cestodes form one taxon, the 'oncophoreans' with an origin separate from that of the trematodes, and that the Gyrocotylidea are modified monogeneans. In contrast, other authors assume the monophyly of all major groups of parasitic Platyhelminthes and do not recognize two groups that have separated early in evolutionary history (e.g. EHLERS 1985, BROOKS 1989, ROHDE 1990).

\section{MATERIAL AND METHODS}

The paper uses various ultrastructural studies, many of them based on serial or semiserial ultrathin sections as described in the cited papers. The DNA studies are based on partial 18s rDNA sequences obtained as described in ROHDE et al. (submitted) and BLAIR (in press).

\section{RESULTS AND DISCUSSION}

Table I gives a summary of the information available on important ultrastructural characteristics of the protonephridia of parasitic Platyhelminthes, illustrated in Figs. 1 and 2.

Tableau I : Liste des genres des Plathelminthes parasites pour lesquels l'ultrastructure des caractères importants des cellules flammes et des capillaires protonéphridiaux est connue. Condensé d'après Rohde (1992).

Table I : Number of genera of parasitic Platyhelminthes for which the ultrastructure of important characters of flame bulbs and protonephridial capillaries is known. Condensed from ROHDE (1992, sources therein).

1a) Septate junction in small capillary and/or flame bulb demonstrated
Digenea
10 genera
(9 families)
Aspidogastrea
3 genera
(2 families)
Monogenea
Polyopisthocotylea
2 genera
(2 families)
Monogenea
Monopisthocotylea
7 genera
(7 families) (and Anoplodiscus : rudimentary)

1b) Lack of septate junction in capillary and/or flame bulb demonstrated
Udonella
1 genus
Amphilinidea
2 genera
Gyrocotylidea
1 genus
Eucestoda
9 genera
(1 family)
(2 families?)
( 1 family)
(8 families)

2a) Lamellae in small capillary demonstrated

$\begin{array}{ll}\text { Digenea } & 9 \text { genera (8 families) } \\ \text { Aspidogastrea } & 3 \text { genera } \\ \text { Mon. Polyop. } & 3 \text { genera } \\ \text { Mon. Monop. } & 3 \text { genera }\end{array}$

2b) Microvilli in small capillary demonstrated
Amphilinidea
Gyrocotylidea
Eucestoda

Eucestoda 16 genera

(2 families)

(3 families)

( 3 families) (In 2 genera of

2 families incl. Anoplodiscus

lack of lamellae demonstrated)
(2 families)
(1 family)

(13 families) 
Twenty two genera of Trematoda Digenea, Aspidogastrea, Monogenea Polyopisthocotylea and Monopisthocotylea examined have a septate junction along the small protonephridial capillaries that extends along the flame bulb between two longitudinal cytoplasmic cords. Such a junction and cytoplasmic cords are absent in Udonella and twelve cestode genera (including Amphilinidea, Gyrocotylidea and Eucestoda) examined.

The surface area of small protonephridial capillaries is enlarged by lamellae in 18 genera of trematodes and monogeneans examined, but such lamellae are absent in 2 genera of Monogenea Monopisthocotylea (including Anoplodiscus). All 19 genera of cestodes, including the amphilinids and gyrocotylids examined, have short microvilli in the capillaries instead. Udonella lacks both microvilli and lamellae.

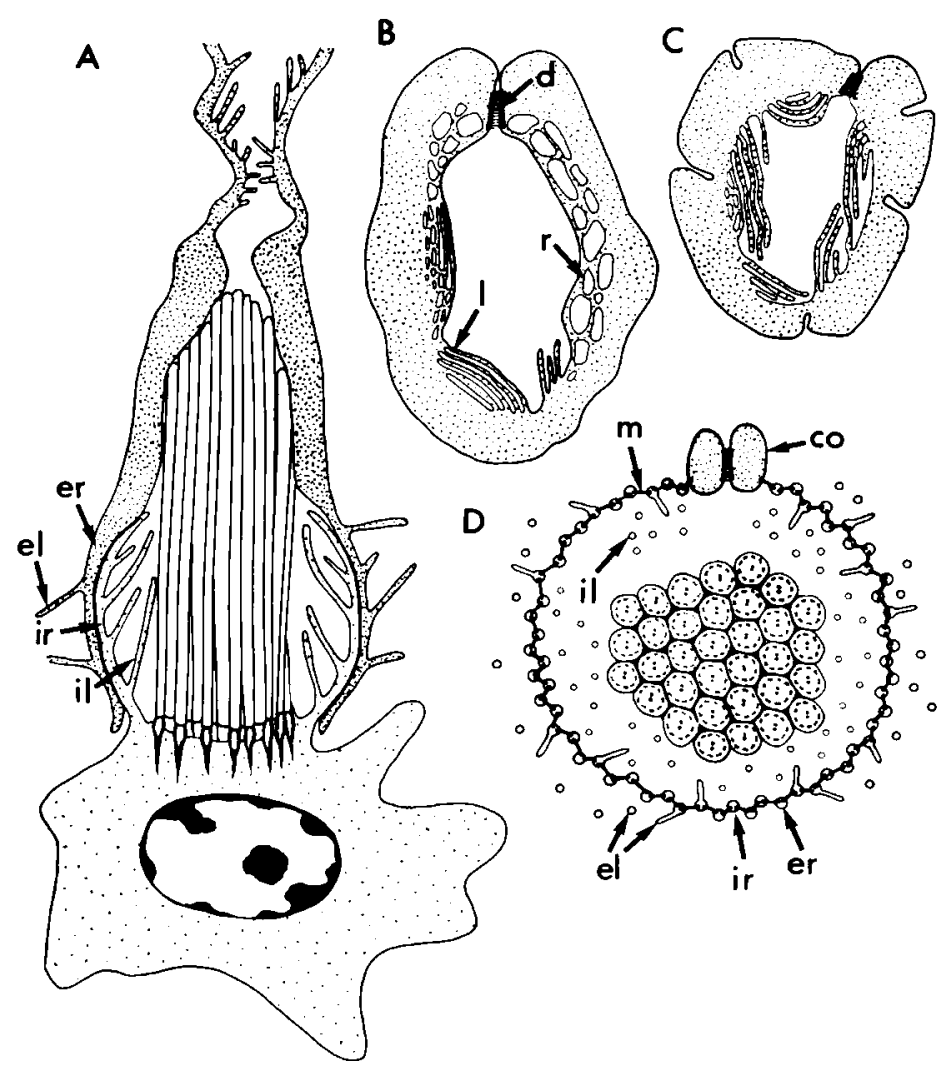

Figure 1 : Diagramme de la cellule flamme et du capillaire protonéphridien d'un Monogène /Trématode.

A - Section longitudinale ; B-C-Sections transversales du capillaire ; D Section transversale de la cellule flamme au niveau de l'appareil de filtration.

CO - Prolongement cytoplasmique ; d - Jonction septée, el - leptotriche externe ; er - côte externe ; il : leptotriche interne ; ir - côte interne ; I lamelle ; $m$ - "membrane"; $r$ - réticulum.

Figure 1 : Diagrams of the flame bulb and protonephridial capillary of a monogenean/trematode.

A. Longitudinal section. B, C. Cross-sections through capillary. D. Cross-section through flame bulb at level of weir (filtration apparatus).

co-cytoplasmic cord, d - septate junction, el - external leptotrich, erexternal rib, il - internal leptotrich, ir - internal rib, I - lamella, m 'membrane', $r$ - reticulum. 
A further difference between the two groups, i.e. Trematoda/Monogenea and Udonella/Cestoda is the presence of well developed external leptotriches in the first and the lack or weak development of such leptotriches in the second group (Fig. 1, 2).

Anoplodiscus, a genus clearly characterized as a monogenean by its two pairs of eyes and 16 larval hooks (OGAWA and EGUSA 1981), is aberrant in several respects: it does not have a proximal-distal fusion of axonemes with the sperm body as found in other Neodermata, but has distal-proximal fusion as found in Turbellaria with axonemes incorporated in the sperm (WATSON and ROHDE, 1992), and it is the only neodermatan in which peculiar uniciliate sensory receptors with perikarya close to the surface have been found (ROHDE and WATSON, unpublished). Its protonephridial system also differs from that of other monogeneans : cytoplasmic cords connected by a septate junction are absent, and a clear junction in the small capillary is also absent (ROHDE et al. 1992). However, presence of a rudimentary junction in the capillaries indicates that the loss is secondary. Since a junction between the cytoplasmic cords in the flame bulb is a continuation of the capillary junction, it is likely that lack of cords and junction in the flame bulb is due to secondary loss as well.

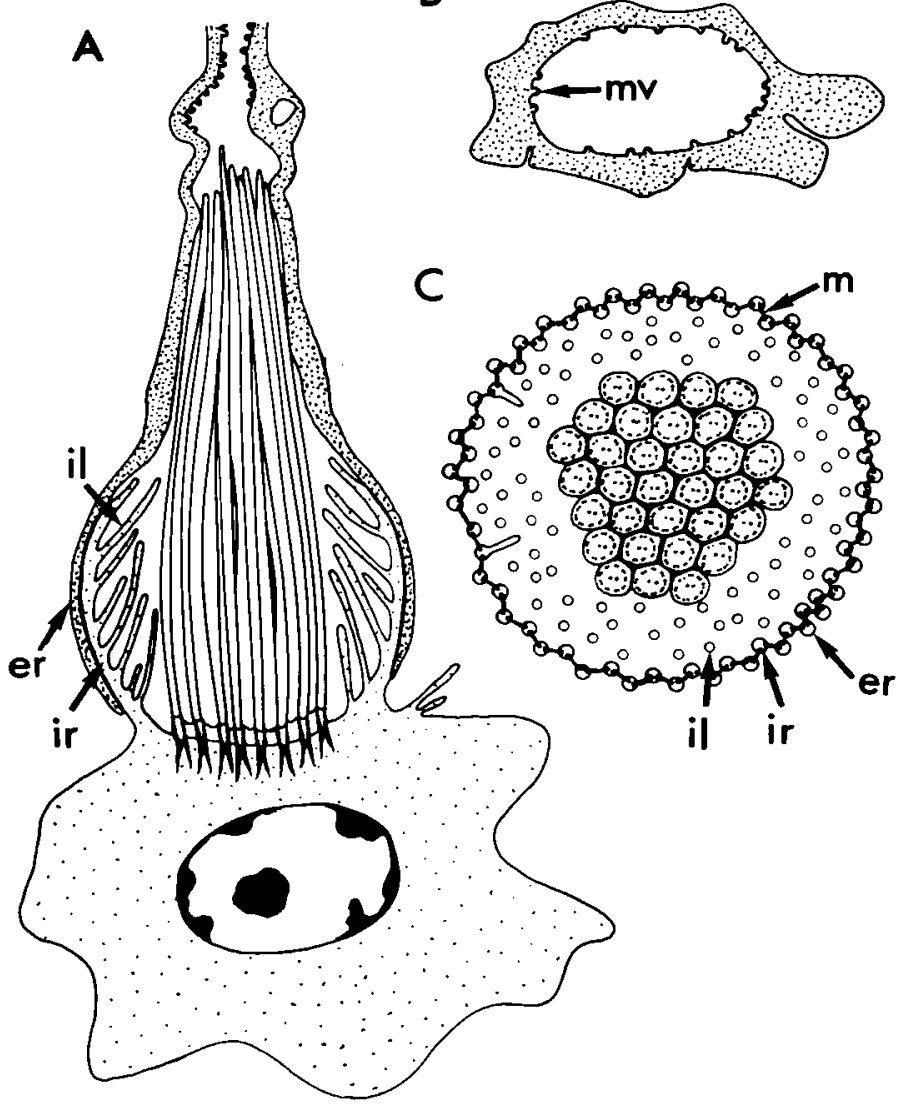

Figure 2 : Diagramme de la cellule flamme et du capillaire protonéphridien d'un Cestode. A - section longitudinale ; B - section transversale du capillaire ; C - section transversale de la cellule flamme au niveau de l'appareil de filtration ; er - côte externe ; il - leptotriche interne ; ir - côte interne ; m "membrane" ; mv - microvillosité.

Figure 2 : Diagrams of the flame bulb and protonephridial capillary of a cestode $A$. Longitudinal section. B. Cross-section through capillary. C. Cross-section through flame bulb at level of weir (filtration apparatus). er - external rib, il - internal leptotrich, ir - internal rib, m - 'membrane', mv microvillus. 


\section{CONCLUSIONS}

The electron-microscopic findings clearly indicate that the Monogenea are more closely related to the Trematoda than to the Cestoda, i.e. the monogeneans cannot be grouped with the cestodes in a taxon Oncophorea that has an origin different from the trematodes. This conclusion is supported by a phylogenetic analysis based on partial DNA sequences : all Neodermata including the Monogenea form one monophylum. Gyrocotyle resembles Udonella, the amphilinids and eucestodes in the structure of its flame bulbs and protonephridial capillaries, and DNA studies also indicate that it is a cestode. BAVERSTOCK et al.'s (1991) conclusion that Gyrocotyle is close to the Monogenea, is based on a wrong alignment of DNA sequences, as pointed out by BLAIR (in press).

\section{ACKNOWLEDGEMENTS}

Financial support was given by the Australian Research Council and the University of New England. Nikki Watson helped with the electron-microscopic studies, and Barbara Rochester typed the manuscript.

\section{REFERENCES}

BAVERSTOCK P.R., FIELKE R., JOHNSON A.M., BRAY R.A., BEVERIDGE I., 1991. Conflicting phylogenetic hypotheses for the parasitic Platyhelminthes tested by partial sequencing of $18 \mathrm{~S}$ ribosomal RNA. Int. J. Parasitol., 21, 329-339.

BLAIR D., in press. Parasitic flatworms and the phylogenetic position of the Aspidobothrea inferred from DNA sequence data. Int. J. Parasitol.,

BROOKS D.R., 1989. The phylogeny of the Cercomeria (Platyhelminthes: Rhabdocoela) and general evolutionary principles. J. Parasitol., 75, 606-616.

CLÉMENT P., FOURNIER A., 1981. Un apparreil excréteur primitif: les protonephridies (Plathelminthes et Nemathelminthes). Bull. Soc. Zool. Fr., 106, 55-67.

EHLERS U., 1985. Das phylogenetische System der Plathelminthes. Gustav Fischer. Stuttgart, New York, $317 \mathrm{p}$.

LLEWELLYN J., 1986. Phylogenetic inference from platyhelminth life-cycle stages. Int. J. Parasitol., 17, 281-289.

OGAWA K., EGUSA S., 1981. The systematic position of the genus Anop/odiscus (Monogenea: Anoplodiscidae). Syst. Zool., 2, 253-260.

ROHDE K., 1988. Phylogenetic relationship of free-living and parasitic Platyhelminthes on the basis of ultrastructural evidence. Fortschr. Zool., 36, 353-357.

ROHDE K., 1990. Phylogeny of Platyhelminthes, with special reference to parasitic groups. Int. J. Parasitol., 20, 979-1007.

ROHDE K., 1991. The evolution of protonephridia of the Platyhelminthes. Hydrobiologia, $227,315-321$.

ROHDE K., WATSON N.A., in press. Secondary sensory receptor in Anoplodiscus. Int. J. Parasitol.,

ROHDE K., WATSON N.A., ROUBAL F.A., 1992. Ultrastructure of the protonephridial system of Anoplodiscus cirrusspiralis (Monogenea, Monopisthocotylea). Int. J. Parasitol., 22, 443-457.

ROHDE K., HEFFORD C., ELLIS J., JOHNSON A.M., BAVERSTOCK P.R., WATSON N.A., DITTMANN S., submitted. Contributions to the phylogeny of Playtyhelminthes based on partial sequencing of $18 \mathrm{~S}$ ribosomal DNA. Int. J. Parasitol.,

WATSON N.A., ROHDE K., 1992. Ultrastructure of sperm and spermatogenesis of Anoplodiscus cirrusspiralis (Monogenea, Monopisthocotylea). Ann. Parasitol. Hum. Comp., 67, 131-141. 